\title{
THREE REVERSED PHASE LIQUID CHROMATOGRAPHIC METHODS FOR THE DETERMINATION OF SOME ANTICHOLENERGIC DRUGS IN THE PRESENCE OF THEIR DEGRADATION PRODUCTS AND/OR IN MIXTURE WITH OTHER DRUGS
}

\author{
Sonia T. Hassib ${ }^{1}$, Naglaa M. El-Kousy ${ }^{2}$ and Al-Shimaa M. Alian ${ }^{2}$ \\ ${ }^{1}$ Department of Pharmaceutical Chemistry, Faculty of Pharmacy, Cairo University, Kasr El- \\ Aini street, Cairo 11562, Egypt \\ ${ }^{2}$ National Organization of Drug Control and Research (NODCAR), Cairo, Egypt
}

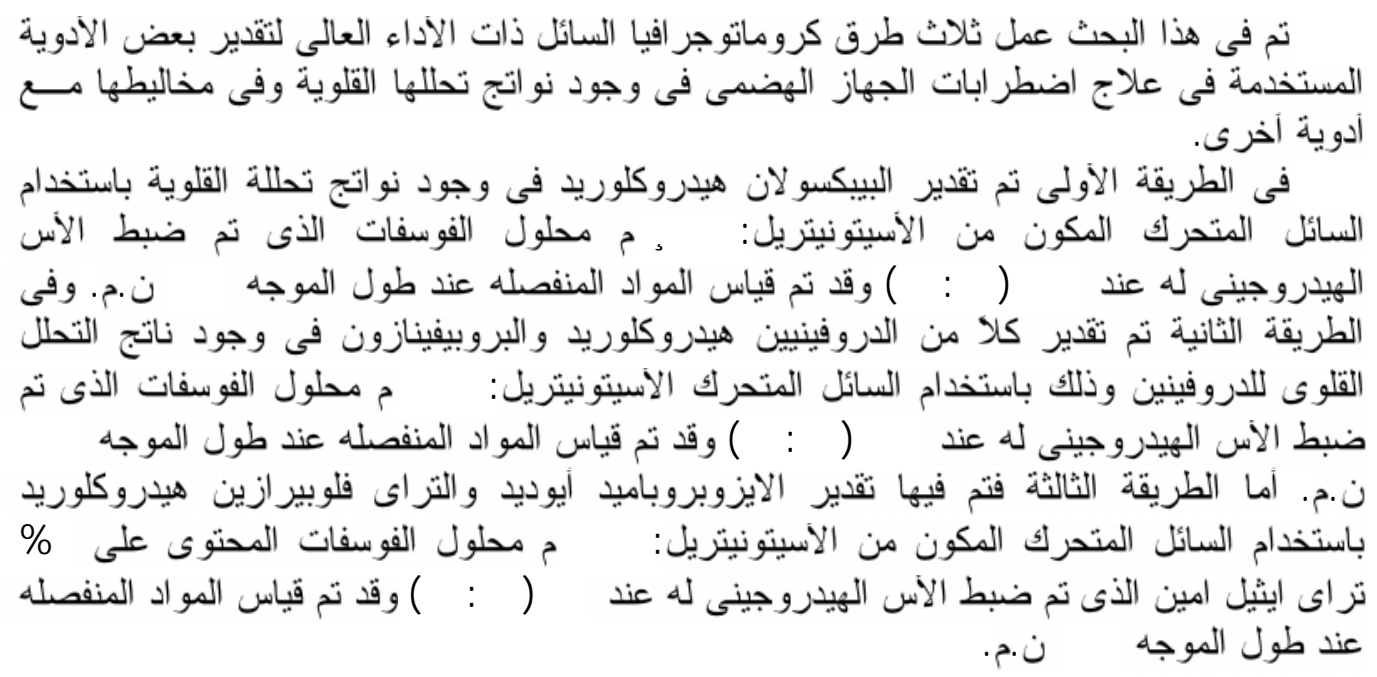

Three RP-LC methods have been developed for the quantitative determination of some anticholinergic drugs in the presence of their degradation products and/or in mixture with other drugs. In method (I) pipoxolan $\mathrm{HCl}$ is estimated in the presence of its alkaline-induced degradation products, $0.02 \mathrm{M}$ phosphate buffer $\mathrm{pH}$ 7.5: acetonitrile $(30: 70 \mathrm{v} / \mathrm{v})$ was used as a mobile phase with UV detection at $215 \mathrm{~nm}$. Drofenine $\mathrm{HCl}$ was used as an internal standard. Method (II) describes the simultaneous determination of drofenine $\mathrm{HCl}$ and propyphenazone in the presence of drofenine $\mathrm{HCl}$ alkaline-induced degradation product. This method used $0.05 \mathrm{M}$ phosphate buffer pH 3.5: acetonitrile $(60: 40 \mathrm{v} / \mathrm{v})$ as a mobile phase with UV detection at 215 $\mathrm{nm}$. In method (III) the simultaneous determination of isopropamide iodide and triflouperazine $\mathrm{HCl}$ is presented. In this method $0.05 \mathrm{M}$ phosphate buffer (containing $0.1 \%$ triethylamine) $\mathrm{pH}$ 3.5: acetonitrile $(50: 50 \mathrm{v} / \mathrm{v})$ was used as a mobile phase with UV detection at $210 \mathrm{~nm}$. Pipoxolan $\mathrm{HCl}$ was used as an internal standard in the determination of the two binary mixtures.

\section{INTRODUCTION}

Pipoxolan hydrochloride, 5, 5-diphenyl-2(2-piperidinoethyl)-1, 3-dioxolan-4-one, is a smooth muscle relaxant ${ }^{1}$ used in the treatment of spasms and colic due to irritable bowel syndrome. In 2010, it was reported that pipoxolan $\mathrm{HCl}$ inhibits the proliferation of $\mathrm{HL}$ 60 human leukemia cancer cell ${ }^{2}$. Its dioxolan moiety was thought to induce apoptosis in cancer cells ${ }^{3}$.

Drofenine hydrochloride, 2-(diethylamino)ethyl $\quad \alpha$-phenylcyclohexaneacetate 
hydrochloride, is an antimuscarinic drug used in the treatment of visceral spasms ${ }^{1}$.

Isopropamide iodide, (3-carbamoyl-3,3diphenylpropyl) di-isopropylmethyl ammonium iodide, is a quaternary ammonium antimuscarinic with peripheral effects similar to those of atropine. It is used as an adjunct in the treatment of peptic ulcer disease, in the relief of gastrointestinal and urinary-tract disorders associated with smooth muscle spasm ${ }^{1}$.

The combination of isopropamide iodide with triflouperazine $\mathrm{HCl}$ provides an optimal and rapid relief in painful conditions associated with visceral spasm.

Propyphenazone, 4-isopropyl-2,3dimethyl-1-phenyl-3-pyrazolin-5-one, is a pyrazolone derivative related to phenazone has analgesic and antipyretic properties ${ }^{1}$
Triflouperazine hydrochloride, 10-[3-(4methylpiperazin-1-yl)propyl]-2-trifluoromethylphenothiazine dihydrochloride, is a phenothiazine antipsychotic drug causes sedation. It is used for the treatment of schizophrenia and other psychoses and for the control of nausea and vomiting ${ }^{1}$.

There is no literature was reported for the determination of pipoxolan $\mathrm{HCl}$.

Several methods have been reported for the determination of drofenine $\mathrm{HCl}$ with allobarbital and aminophenazone by gas chromatography ${ }^{4}$ and by LC methods ${ }^{5-7}$.

Several methods have been reported for the determination of isopropamide iodide with triflouperazine $\mathrm{HCl}$ by spectrophotometric methods $^{8-10}$ and with other drugs by LC methods ${ }^{11-13}$.<smiles>O=C1OC(CCN2CCCCC2)OC1(c1ccccc1)c1ccccc1</smiles>

Pipoxolan $\mathrm{HCl}$
. $\mathrm{HCl}$<smiles>CCN(C)CCOC(=O)C(c1ccccc1)C1CCCCC1</smiles>

Drofenine $\mathrm{HCl}$<smiles>Cc1c(C(C)C)c(=O)n(-c2ccccc2)n1C</smiles>

Propyphenazone

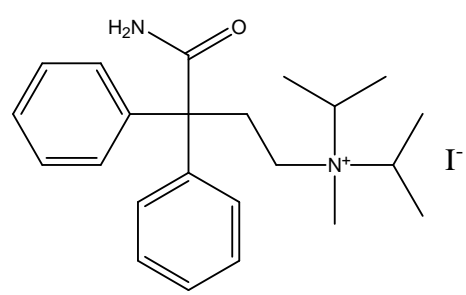

Isopropamide iodide

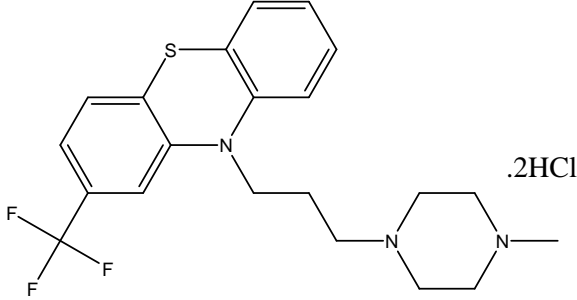

Triflouperazine $\mathrm{HCl}$

\section{Chemical structure of pipoxolan $\mathrm{HCl}$, drofenine $\mathrm{HCl}$, propyphenazone, isopropamide iodide and triflouperazine $\mathrm{HCl}$.}




\section{EXPERIMENTAL}

\section{Materials}

Pipoxolan $\mathrm{HCl}$ working standard was kindly supplied by Amoun pharmaceutical Co., Cairo, Egypt. Its purity was found to be 100.33 $\pm 0.587(\mathrm{n}=6)$ according to the manufacturer's method $^{14}$. Drofenine $\mathrm{HCl}$ and propyphenazone were kindly supplied by Pharco Co., Alex, Egypt. Their purities were found to be $99.84 \pm$ 0.584 and $99.51 \pm 0.795(\mathrm{n}=6)$ according to the manufacturer's method ${ }^{15}$ for drofenine $\mathrm{HCl}$ and European pharmacopoeia $(2008)^{16}$ for propyphenazone respectively. Isopropamide iodide and triflouperazine $\mathrm{HCl}$ were kindly supplied by Kahira pharmaceutical and chemical Industrial Co., Cairo, Egypt. Their purities were found to be $100.04 \pm 0.788$ and $99.50 \pm 0.584(n=6)$ according to USP $32^{17}$ for isopropamide iodide and European pharmacopoeia $(2008)^{16}$ for triflouperazine $\mathrm{HCl}$.

\section{Dosage forms}

Rowapraxin tablets (Amoun pharmaceutical Co., Cairo, Egypt). Each tablet contains $10 \mathrm{mg}$ pipoxolan $\mathrm{HCl}$.

Spasmo-cibalgin tablets (Novartis pharma AG Basle, Zwitzerland). Each tablet contains $220 \mathrm{mg}$ propyphenazone and $20 \mathrm{mg}$ drofenine $\mathrm{HCl}$.

Stellamide tablets (Kahira pharmaceutical and chemical Industrial Co., Cairo, Egypt). Each tablet contains $1 \mathrm{mg}$ triflouperazine $\mathrm{HCl}$ and $5 \mathrm{mg}$ isopropamide iodide.

\section{Apparatus}

a- Balance (scaltec, Germany)

b- Microprocessor $\mathrm{pH}$ meter - $\mathrm{pH}$ meter 211 (Hanna, Portugal).

c- Filter - disposable Nylon membrane filters $0.45 \mathrm{~m}$ pore size (Whatman, International Ltd, Maidtone, England).

d- The LC system - consisting of Agilent 1100 series, interface equipped with an Agilent degasser JP3060993 (Japan), an Agilent quaternary pump DE62962767 (Germany), an Agilent manual injector DE60558338 equipped with $(100 \mu \mathrm{l})$ injector loop, an Agilent column thermostat DE63065412 (Germany) and an Agilent UV-visible detector (Germany).
Agilent syringe, LC $250 \mu \mathrm{l}$ (USA).

Hypersil BDS-C8 column - 4 x $250 \mathrm{~mm}, 5$ $\mathrm{m}$, SN USUE000254 (USA) was used in method (I) and (II).

Hypersil thermo-C8 column - 4.6 × $250 \mathrm{~mm}$, $5 \mathrm{~m}, \mathrm{SN}$ 0471929M (USA) was used in method (III).

\section{Chemicals and reagents}

All chemicals and solvents were analytical grade otherwise specified.

a-Chemicals - Sodium hydroxide and potassium dihydrogen orthophosphate (pure lab. EL-Nasr pharmaceutical Co., Egypt). Hydrocholric acid 37\% (Riedel-de Haen, Germany). Orthophosphoric acid analar (BDH, England). Triethylamine (s d finechem limited, Mumbai)

b- Solvents - Acetonitrile (LC grade s d finechem limited, Mumbai)

Distilled water

c- Diluting solution - Acetonitrile : water $(50: 50 \mathrm{v} / \mathrm{v})$

d-Mobile phases- All mobile phases were filtered through $0.45 \mathrm{~m}$ membrane filter and degassed for $30 \mathrm{~min}$ in an ultrasonic bath prior to its use.

In method (I): $0.02 \mathrm{M}$ phosphate buffer $\mathrm{pH}$ 7.5 (prepared by dissolving $2.72 \mathrm{gm}$ potassium dihydrogen orthophosphate in $900 \mathrm{ml}$ distilled water adjusted to $\mathrm{pH} 7.5$ with $10 \%$ sodium hydroxide to a $\mathrm{pH} 7.5 \pm 0.1$ and diluted with distilled water to $1000 \mathrm{ml})$ : acetonitrile (30:70 $\mathrm{v} / \mathrm{v})$.

In method (II): $0.05 \mathrm{M}$ phosphate buffer $\mathrm{pH}$ 3.5 (prepared by dissolving 6.8 gm potassium dihydrogen orthophosphate in $900 \mathrm{ml}$ distilled water, adjusted to $\mathrm{pH} 3.5 \pm 0.1$ with orthophosphoric acid and diluted with distilled water to $1000 \mathrm{ml})$ : acetonitrile $(60: 40 \mathrm{v} / \mathrm{v})$.

In method (III): $0.05 \mathrm{M}$ phosphate buffer $\mathrm{pH}$ 3.5 (prepared by dissolving 6.8 gm potassium dihydrogen orthophosphate in $900 \mathrm{ml}$ distilled water containing $1 \mathrm{ml}$ triethylamine and adjusted to $\mathrm{pH} 3.5 \pm$ with orthophosphoric acid then diluted with distilled water to $1000 \mathrm{ml}$ ): acetonitrile $(50: 50 \mathrm{v} / \mathrm{v})$. 


\section{Preparation of sample}

\section{Standard solutions}

Pipoxolan $\mathrm{HCl}$ stock solution $\left(0.1 \mathrm{mg} \mathrm{ml}^{-1}\right)$ was prepared by dissolving accurately weighed $10 \mathrm{mg}$ of into $100 \mathrm{ml}$ volumetric flask, and completing to the volume with the diluting solution.

Drofenine $\mathrm{HCl}$ stock solution $(0.2 \mathrm{mg} / \mathrm{ml})$ and propyphenazone $(0.1 \mathrm{mg} / \mathrm{ml})$ were prepared by introducing accurately weighed 20 $\mathrm{mg}$ of and $10 \mathrm{mg}$ of into two separate $100 \mathrm{ml}$ volumetric flasks, dissolving and completing to the volume with the diluting solution.

Isopropamide iodide and triflouperazine $\mathrm{HCl}$ stock solutions $(0.1 \mathrm{mg} / \mathrm{ml})$ each were prepared by dissolving accurately weighed 10 $\mathrm{mg}$ of and $10 \mathrm{mg}$ of into two separate $100 \mathrm{ml}$ volumetric flasks, and completing to the volume with the diluting solution.

\section{Degradation product stock solutions}

An accurate weight $(50 \mathrm{mg})$ of each of pipoxolan $\mathrm{HCl}$ and drofenine $\mathrm{HCl}$ was refluxed separately with $25 \mathrm{ml} 1 \mathrm{~N} \mathrm{NaOH}$ for $4 \mathrm{hr}$ then neutralize with $1 \mathrm{~N} \mathrm{HCl}$ and completed to 100 $\mathrm{ml}$ with water. Accurately measured aliquots of these solutions equivalent to $10 \mathrm{mg}$ of pipoxolan $\mathrm{HCl}$ and $20 \mathrm{mg}$ of drofenine $\mathrm{HCl}$ were introduced separately into two $100 \mathrm{ml}$ volumetric flasks and completed to the volume with the diluting solution.

\section{Calibration}

\section{For pipoxolan $\mathrm{HCl}$ (method I)}

Accurately measured aliquots equivalent to $(100-600 \mathrm{~g})$ of pipoxolan $\mathrm{HCl}$ from its stock solution were transferred into a series of $10 \mathrm{ml}$ volumetric flasks. An aliquot equivalent to $(50 \mathrm{~g})$ of drofenine $\mathrm{HCl}$ (internal standard) was added to each volumetric flask and the volume was completed with the diluting solvent. A volume $100 \mu \mathrm{l}$ of each dilution was injected in triplicate; the chromatograms were recorded using $0.02 \mathrm{M}$ phosphate buffer $\mathrm{pH} 7.5$ : acetonitrile $(30: 70 \mathrm{v} / \mathrm{v})$ as the mobile phase. The elution was carried out at ambient temperature using UV detection at $215 \mathrm{~nm}$ and a flow rate $1.5 \mathrm{ml} / \mathrm{min}$.

\section{For drofenine $\mathrm{HCl}$ and propyphenazone (method II)}

Accurately measured aliquots equivalent to $(200-1400 \mathrm{~g})$ of drofenine $\mathrm{HCl}$ and (100-
$700 \mathrm{~g}$ ) of propyphenazone from their stock solutions were transferred separately into two series of $10 \mathrm{ml}$ volumetric flasks. An aliquot equivalent to $(50 \mathrm{~g})$ of pipoxolan $\mathrm{HCl}$ (internal standard) was added to each volumetric flask and the volume was completed with the diluting solvent. A volume $100 \mu \mathrm{l}$ of each dilution was injected in triplicate; the chromatograms were recorded using $0.05 \mathrm{M}$ phosphate buffer $\mathrm{pH}$ 3.5: acetonitrile (60:40 $\mathrm{v} / \mathrm{v})$ as the mobile phase. The elution was carried out at ambient temperature using UV detection at $215 \mathrm{~nm}$ and a flow rate $1.5 \mathrm{ml} / \mathrm{min}$.

\section{For isopropamide iodide and triflouperazine HCl (method III)}

Accurately measured aliquots equivalent to $(100-600 \mathrm{~g})$ of isopropamide iodide and $(100-600 \mathrm{~g})$ of triflouperazine $\mathrm{HCl}$ from their stock solutions were transferred separately into two series of $10 \mathrm{ml}$ volumetric flasks. An aliquot equivalent to $(50 \mathrm{~g})$ of pipoxolan $\mathrm{HCl}$ (internal standard) was added to each volumetric flask and the volume was completed with the diluting solvent. A volume $100 \mu \mathrm{l}$ of each dilution was injected in triplicate, the chromatograms were recorded using $0.05 \mathrm{M}$ phosphate buffer $\mathrm{pH} 3.5$ (containing $1 \mathrm{ml} / \mathrm{l}$ triethylamine): acetonitrile $(50: 50 \mathrm{v} / \mathrm{v})$ as the mobile phase. The elution was carried out at ambient temperature using UV detection at 210 $\mathrm{nm}$ and a flow rate $1.5 \mathrm{ml} / \mathrm{min}$.

The ratios $(\mathrm{R})$ of the recorded area under the peak (AUP) of each drug to that of the internal standard were plotted versus the corresponding concentrations in $\mu \mathrm{g} / \mathrm{ml}$ to obtain the calibration curve of each drug and the corresponding regression equations were computed.

\section{Assay of laboratory prepared mixtures For pipoxolan $\mathrm{HCl}$}

Aliquots from pipoxolan $\mathrm{HCl}$ and its alkaline-induced degradation products (1\&2) stock solutions equivalent to pipoxolan $\mathrm{HCl}$ $(0.20-0.55 \mathrm{mg})$ and degradation products (1\&2) $(0.05-0.40 \mathrm{mg})$ were transferred into one series of $10 \mathrm{ml}$ volumetric flasks. An aliquot equivalent to $(50 \mathrm{~g})$ of drofenine $\mathrm{HCl}$ (internal standard) was added to each flask and the volume was completed with the diluting solution. 


\section{For drofenine $\mathrm{HCl}$}

Aliquots from drofenine $\mathrm{HCl}$ and its alkaline-induced degradation product (3) stock solutions equivalent to drofenine $\mathrm{HCl}(0.55-$ $1.25 \mathrm{mg})$ and degradation product (3) (0.15 $0.85 \mathrm{mg}$ ) were transferred into one series of 10 $\mathrm{ml}$ volumetric flasks. An aliquot equivalent to $(50 \mathrm{~g})$ of pipoxolan $\mathrm{HCl}$ (internal standard) was added to each flask and the volume was completed with the diluting solution.

The chromatographic conditions were applied for each laboratory prepared mixture and the concentrations of each drug in these mixtures were calculated by substituting the regression equation for each drug.

\section{Application to pharmaceutical preparations}

Twenty tablets of each of Rowapraxine tablets, Spasmocebalgin tablets and Stellamide tablets were weighed, ground and an accurate weight of the powdered tablets equivalent to $(10 \mathrm{mg})$ pipoxolan $\mathrm{HCl}$ in case of Rowapraxine tablets, $(20 \mathrm{mg})$ drofenine $\mathrm{HCl}$ in case of Spasmocebalgin tablets and $(10 \mathrm{mg})$ isopropamide iodide in case of Stellamide tablets were introduced separately into $100 \mathrm{ml}$ volumetric flask, $80 \mathrm{ml}$ diluting solution was added and the solution was sonicated for 30 min. The volume was completed with the diluting solution, $(0.1 \mathrm{mg} / \mathrm{ml})$ pipoxolan $\mathrm{HCl}$ in case of Rowapraxine tablets, $(0.2 \mathrm{mg} / \mathrm{ml})$ drofenine $\mathrm{HCl}$ in case of Spasmocebalgin tablets and $(0.1 \mathrm{mg} / \mathrm{ml})$ isopropamide iodide in case of Stellamide tablets the solutions were filtered and the first $10 \mathrm{ml}$ of the filtrate was rejected.

Each pharmaceutical preparation was analyzed according to instrumental parameter as under linearity.

\section{RESULTS AND DISCUSSION}

Pipoxolan $\mathrm{HCl}$ containing a dioxolan moiety which is important for its activity ${ }^{3}$ so it was necessary to develop simple stability indicating assay method for the determination of pipoxolan $\mathrm{HCl}$ in presence of its alkalineinduced degradation products. However, by reviewing the literature concerning the determination of this drug, it was found that no literature was reported for the determination of pipoxolan $\mathrm{HCl}$ by $\mathrm{LC}$ either alone or with its degradation products. Several mobile phases with different ratios for their components were tried such as:

- Water $\mathrm{pH}$ 4.5: methanol (25-50 : 75-50 $\mathrm{v} / \mathrm{v})$.

- Water $\mathrm{pH}$ 4.5: acetonitrile (25-50 : 75-50 $\mathrm{v} / \mathrm{v})$.

- Phosphate buffer pH 4.5 : acetonitrile (30$70: 70-30 \mathrm{v} / \mathrm{v})$.

- Water : methanol : acetonitrile (70:15:15, $50: 25: 25,20: 40: 40 \mathrm{v} / \mathrm{v} / \mathrm{v})$

- $0.02 \mathrm{M}$ phosphate buffer $\mathrm{pH} 7.5$ : acetonitrile $(30-75: 70-30 \mathrm{v} / \mathrm{v})$.

A satisfactory separation was obtained with the mobile phase $0.02 \mathrm{M}$ phosphate buffer $\mathrm{pH} 7.5$ : acetonitrile $(30: 70 \mathrm{v} / \mathrm{v})$ as it showed good separation of pipoxolan $\mathrm{HCl}$ and degradation products $(1 \& 2)$ at retention time for pipoxolan $\mathrm{HCl} 4.994 \mathrm{~min}$ and for degradation products (1\&2) $1.815 \mathrm{~min}$ and $2.400 \mathrm{~min}$, respectively. Drofenine $\mathrm{HCl}$ was chosen as internal standard as it eluted at reasonable retention time $7.046 \mathrm{~min}$ and showed good separation from mixture components (Fig. 1). The formation of two degradation products of much higher polarity than pipoxolan $\mathrm{HCl}$ as shown by their retention time [degradation product (1) 1.815, degradation product (2) 2.400 and pipoxolan $\mathrm{HCl} 4.994 \mathrm{~min}]$ could be attributed to the cleavage of the lactone group giving a product with a $\mathrm{COOH} \& \mathrm{OH}$ groups [degradation product (1) $1.815 \mathrm{~min}]$.

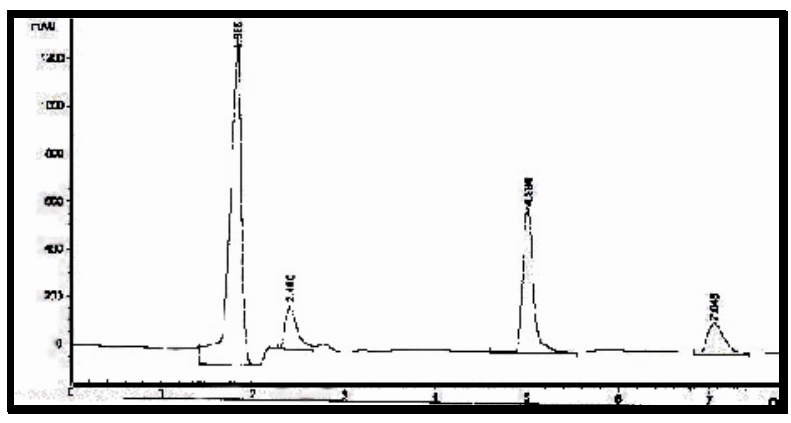

Fig. 1: The chromatogram of pipoxolan $\mathrm{HCl}(4.994$ min), its alkaline-induced degradation products (1.815 and $2.400 \mathrm{~min})$ and drofenine $\mathrm{HCl}(7.046 \mathrm{~min})$ as internal standard.

Decarboxylation of degradation product (1) gives a degradation product containing $\mathrm{OH}$ with less polarity than the first [degradation product (2) $2.400 \mathrm{~min}$ ]. 


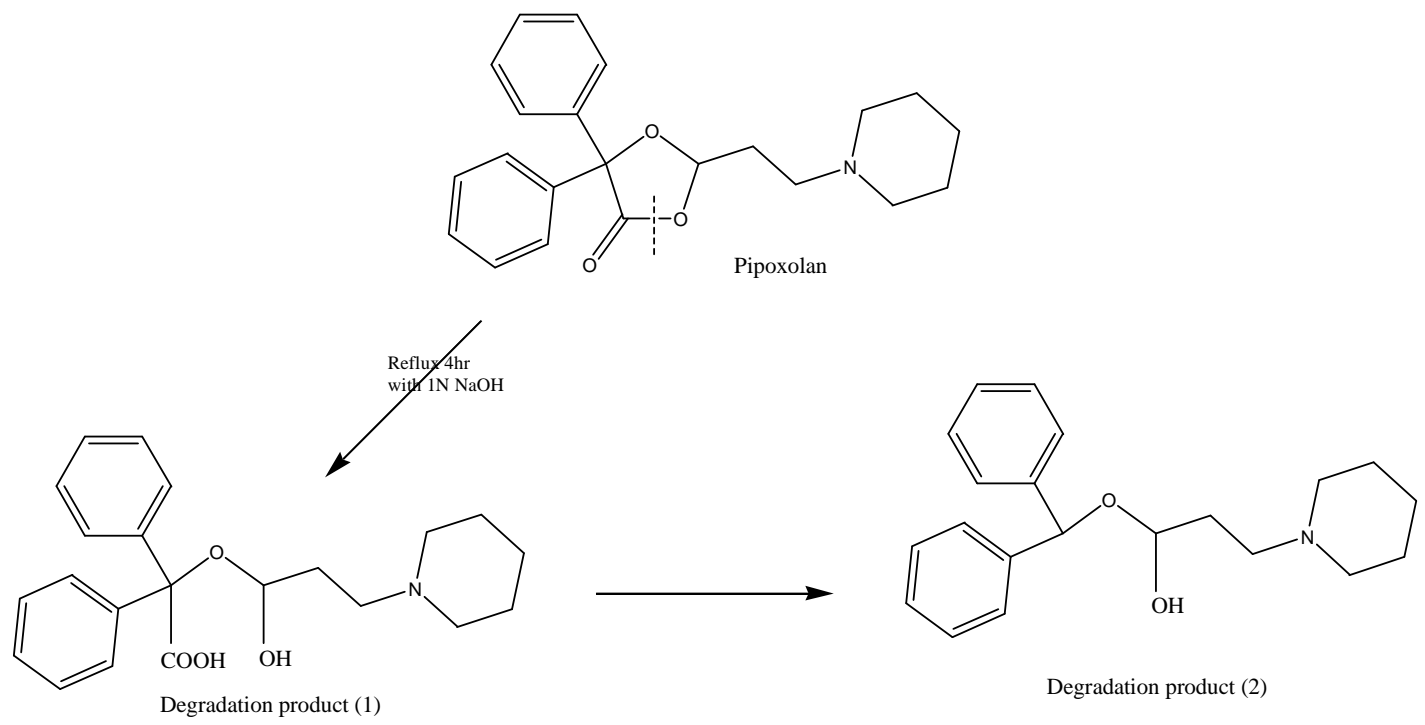

Drofenine $\mathrm{HCl}$ and propropyphenazone are present in a binary mixture. On literature survey, no literature describing the simultaneous determination of these two drugs by $\mathrm{LC}$ was found. Drofenine $\mathrm{HCl}$ and its degradation product cyclohexane phenyl acetic acid were estimated using spherisorb ODS column and mobile phase containing acetonitrile : $0.02 \mathrm{M}$ sodium acetate buffer solution with $0.59 \%$ of di-n-butylamine $655: 35$ $\mathrm{v} / \mathrm{v})$ adjusted to $\mathrm{pH} 4.5$ with acetic acid at a flow rate $1.5 \mathrm{ml} / \mathrm{min}$ and detection at $260 \mathrm{~nm}$ but poor peak shapes were observed for drofenine $\mathrm{HCl}$ and cyclohexane phenyl acetic acid (tailing factor for drofenine $\mathrm{HCl}=4.6$ and for cyclohexane phenyl acetic acid $=2.42)^{7}$.

Several mobile phases with different ratios for their components were tried for the separation of drofenine $\mathrm{HCl}$, propyphenazone and degradation product (3) such as:

- Water pH 4.5 : methanol: (25-50 : 75-50 $\mathrm{v} / \mathrm{v})$.

- Phosphate buffer $\mathrm{pH}$ 4.5: acetonitrile (30$70: 70-30 \mathrm{v} / \mathrm{v})$.

- $0.02 \mathrm{M}$ phosphate buffer $\mathrm{pH}$ 7.5: acetonitrile $(30: 70,20: 80 \mathrm{v} / \mathrm{v})$.

- $0.05 \mathrm{M}$ phosphate buffer $\mathrm{pH}$ 3.5: acetonitrile (30-70 : 70-30).

The chosen mobile phase was $0.05 \mathrm{M}$ phosphate buffer $\mathrm{pH}$ 3.5: acetonitrile (60:40 $\mathrm{v} / \mathrm{v})$ as it showed good separation of drofenine $\mathrm{HCl}$, degradation product (3), pipoxolan $\mathrm{HCl}$ and propyphenazone at a flow rate of 1.5 $\mathrm{ml} / \mathrm{min}$ and UV detection at $215 \mathrm{~nm}$. Retention time for drofenine $\mathrm{HCl}$ was $7.010 \mathrm{~min}$, for degradation product (3) was $13.807 \mathrm{~min}$ and for propyphenazone was 3.645 min pipoxolan $\mathrm{HCl}$ was chosen as internal standard as it eluted at reasonable retention time at $4.564 \mathrm{~min}$ and showed good separation from mixture components (Fig. 2).

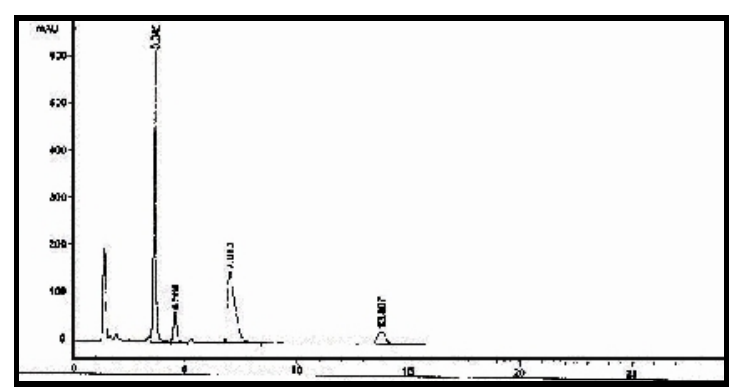

Fig. 2: The chromatogram of propyphenazone (3.645 $\mathrm{min})$, pipoxolan $\mathrm{HCl}(4.564 \mathrm{~min})$ as internal standard drofenine $\mathrm{HCl}(7.010 \mathrm{~min})$ and its alkaline-induced degradation product (13.807 $\mathrm{min})$.

Isopropamide iodide and triflouperazine $\mathrm{HCl}$ are present in a binary mixture. On literature survey, no literature describing the simultaneous determination of these two drugs by LC was found. Different mobile phases were tried such as:

- $\mathrm{NaH}_{2} \mathrm{PO}_{4}$ buffer pH 5.5 : acetonitrile with different ratios: (30-70:70-30 v/v).

- $\mathrm{NaH}_{2} \mathrm{PO}_{4}$ buffer $\mathrm{pH}$ 5.5: acetonitrile: methanol $(50: 30: 20 \mathrm{v} / \mathrm{v} / \mathrm{v})$.

- $0.02 \mathrm{M}$ Ammonium acetate buffer: acetonitrile with different ratios: (55:45 $\mathrm{v} / \mathrm{v})$. 
- $0.05 \mathrm{M}$ Phosphate buffer $\mathrm{pH} 3.5$ : acetonitrile with different ratios: (30-70 : $70-30 \mathrm{v} / \mathrm{v})$

- $0.05 \mathrm{M}$ Phosphate buffer $\mathrm{pH} 3.5$ (containing $1 \mathrm{ml} / \mathrm{l}$ triethylamine) : acetonitrile $(50: 50 \mathrm{v} / \mathrm{v})$.

The chosen mobile phase was $0.05 \mathrm{M}$ phosphate buffer pH 3.5 (containing $1 \mathrm{ml} / 1$ triethylamine): acetonitrile $(50: 50 \mathrm{v} / \mathrm{v})$ as it showed good separation of isopropamide iodide and triflouperazine $\mathrm{HCl}$ at a flow rate of $1.5 \mathrm{ml} / \mathrm{min}$ and UV detection at $210 \mathrm{~nm}$. Retention time for isopropamide iodide was $3.729 \mathrm{~min}$ and for triflouperazine $\mathrm{HCl}$ was 7.115 min. Pipoxolan $\mathrm{HCl}$ was chosen as internal standard as it eluted at reasonable retention time at $5.709 \mathrm{~min}$ and showed good separation from mixture components (Fig. 3).

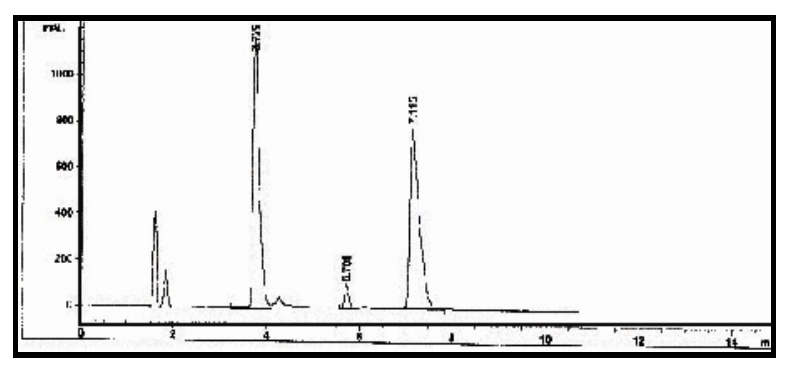

Fig. 3: The chromatogram of isopropamide iodide (3.729 $\mathrm{min})$, pipoxolan $\mathrm{HCl}$ (5.709 $\mathrm{min}$ ) as internal standard and triflouperazine $\mathrm{HCl}$ (7.115 $\mathrm{min})$.
System suitability tests of LC method shows good resolution for the drugs, (Table 1).

Linear relationship was obtained between the ratios $(\mathrm{R})$ of the recorded area under the peaks of each drug to that of the internal standard. The concentration ranges and the regression equations are displayed in tables 2-4.

The results of assay validation of the proposed methods show that the methods are accurate, precise and specific according to the $\%$ RSD of intraday and interday determination, (Tables 2-4).

A statistical comparison of the results obtained by the proposed methods and reference methods that depends on colorimetric determination of pipoxolan $\mathrm{HCl}^{14}$ and drofenine $\mathrm{HCl}^{15}$, official methods; potentiometric titration of propyphenazone ${ }^{16}$ and triflouperazine $\mathrm{HCl}^{16}$ and non-aqueous titration of isopropamide iodide ${ }^{17}$. The values of the calculated $\mathrm{t}$ and $\mathrm{F}$ are less than the tabulated ones, which reveals that there is no significant difference with respect to accuracy and precision between the proposed and the reference methods, (Table 5).

Table 1: System suitability tests for the LC methods proposed for the determination of pipoxolan $\mathrm{HCl}$, drofenine $\mathrm{HCl}$ and propyphenazone in presence of their alkaline-induced degradation products and isopropamide iodide - triflouperazine $\mathrm{HCl}$ binary mixture.

\begin{tabular}{|c|c|c|c|c|c|c|c|c|c|c|}
\hline & \multicolumn{3}{|c|}{ Method (I) } & \multicolumn{4}{|c|}{ Method (II) } & \multicolumn{3}{|c|}{ Method (III) } \\
\hline Item & $\begin{array}{l}\text { Degrada- } \\
\text { tion } \\
\text { product } \\
(2) \\
\end{array}$ & $\begin{array}{c}\text { Pipoxolan } \\
\mathrm{HCl}\end{array}$ & $\begin{array}{c}\text { Drofenine } \\
\mathrm{HCl} \\
\text { (internal } \\
\text { standard) }\end{array}$ & $\begin{array}{l}\text { Propyphena- } \\
\text { zone }\end{array}$ & $\begin{array}{c}\text { Pipoxolan } \\
\mathrm{HCl} \\
\text { (internal } \\
\text { standard) }\end{array}$ & $\begin{array}{c}\text { Drofenine } \\
\mathrm{HCl}\end{array}$ & $\begin{array}{l}\text { Degrada- } \\
\text { tion } \\
\text { product } \\
(3) \\
\end{array}$ & $\begin{array}{l}\text { Isopropam- } \\
\text { ide iodide }\end{array}$ & $\begin{array}{c}\text { Pipoxolan } \\
\mathrm{HCl} \\
\text { (internal } \\
\text { standard) }\end{array}$ & $\begin{array}{c}\text { Triflou- } \\
\text { perazine } \\
\mathrm{HCl}\end{array}$ \\
\hline $\begin{array}{l}\text { N(number } \\
\text { of } \\
\text { theoretical } \\
\text { plates) }\end{array}$ & 2167 & 10472 & 6946 & 6761 & 6721 & 2358 & 6833 & 4273 & 19164 & 6292 \\
\hline $\begin{array}{c}\mathrm{R} \\
\text { (resolution) }\end{array}$ & \multicolumn{2}{|c|}{12.90} & 7.68 & \multicolumn{2}{|l|}{4.59} & 6.10 & 10.90 & \multicolumn{2}{|l|}{10.06} & 5.36 \\
\hline $\begin{array}{c}\alpha \\
\text { (selectivity) }\end{array}$ & \multicolumn{2}{|c|}{2.08} & 1.41 & \multicolumn{2}{|l|}{2.08} & 1.54 & 1.97 & \multicolumn{2}{|l|}{1.53} & 1.25 \\
\hline $\begin{array}{c}\mathrm{K} \text { (capacity } \\
\text { factor) }\end{array}$ & --- & 1.774 & 2.914 & 1.69 & 2.37 & 4.19 & 9.22 & 1.04 & 2.12 & 2.89 \\
\hline $\begin{array}{l}\mathrm{T} \text { (tailing } \\
\text { factor) }\end{array}$ & --- & 1.330 & 1.400 & 1.10 & 1.20 & 1.49 & 1.03 & 1.30 & 1.00 & 1.14 \\
\hline
\end{tabular}


Table 2: Assay validation results obtained by the proposed LC method for the determination of pipoxolan $\mathrm{HCl}$ in presence of its alkaline-induced degradation products.

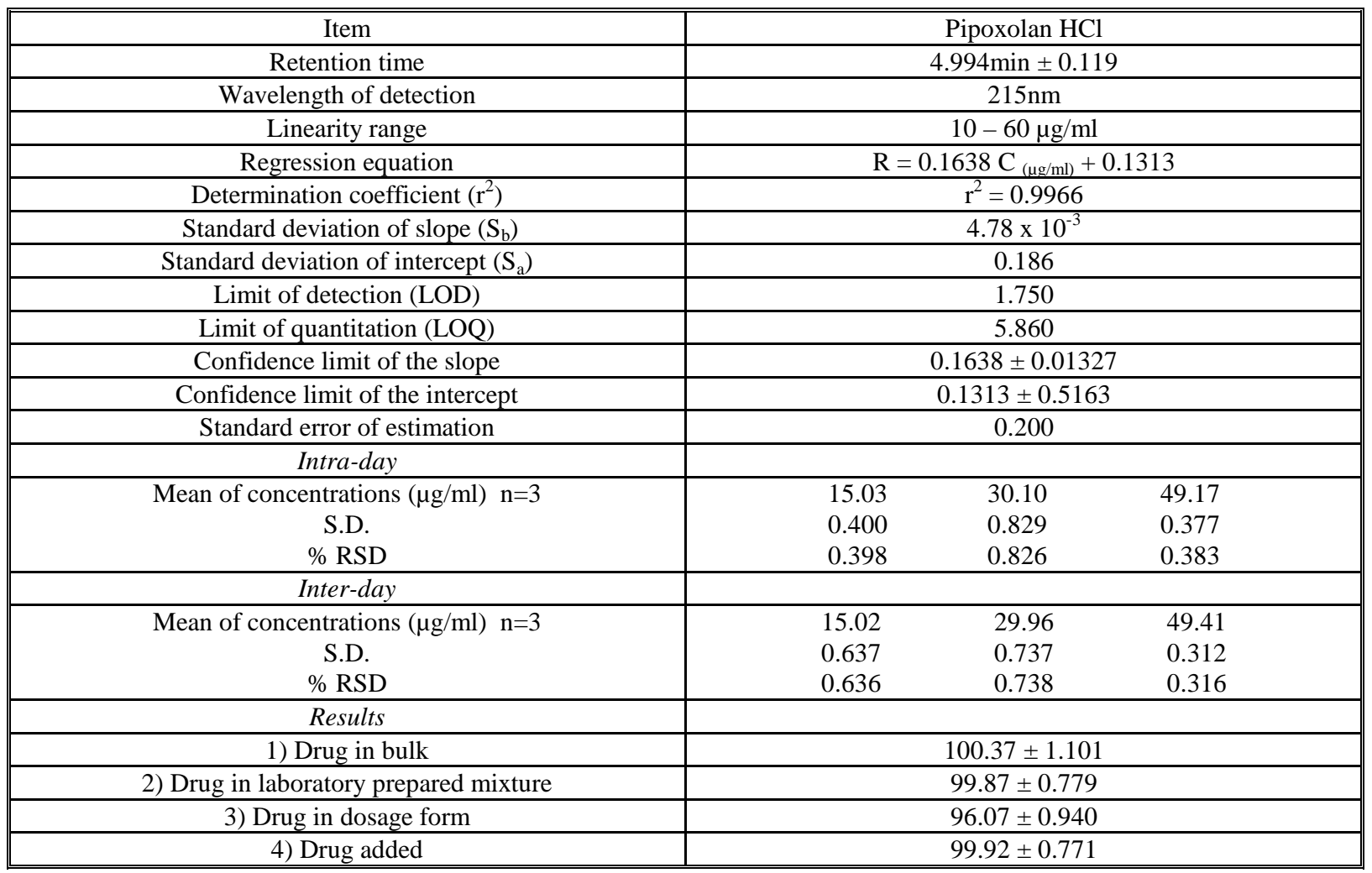

Table 3: Assay validation results obtained by the proposed HPLC method for the determination of drofenine $\mathrm{HCl}$ and propyphenazone in presence of drofenine alkaline-induced degradation product.

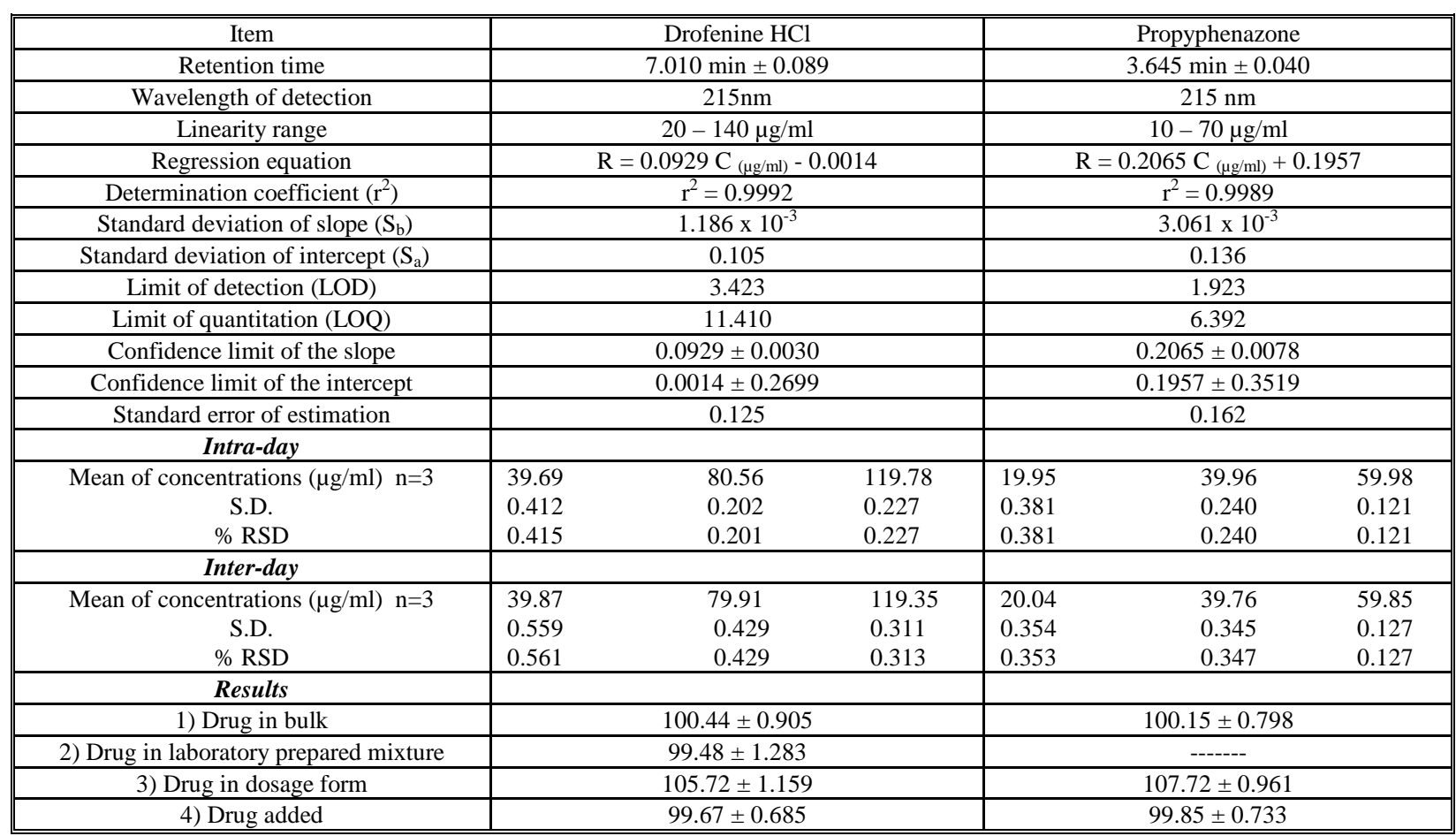


Table 4: Assay validation results obtained by the proposed LC method for the simultaneous determination of isopropamide iodide and triflouperazine $\mathrm{HCl}$ in mixture.

\begin{tabular}{|c|c|c|c|c|}
\hline Item & Isopropamide iodide & \multicolumn{3}{|c|}{ Triflouperazine $\mathrm{HCl}$} \\
\hline Retention time & $3.729 \min \pm 0.043$ & \multicolumn{3}{|c|}{$7.115 \min \pm 0.085$} \\
\hline Wavelength of detection & $210 \mathrm{~nm}$ & \multicolumn{3}{|c|}{$210 \mathrm{~nm}$} \\
\hline Linearity range & $10-60 \mathrm{~g} / \mathrm{ml}$ & \multicolumn{3}{|c|}{$10-60 \mathrm{~g} / \mathrm{ml}$} \\
\hline Regression equation & $\mathrm{R}=0.2506 \mathrm{C}_{(\mathrm{g} / \mathrm{ml})}+0.0773$ & \multicolumn{3}{|c|}{$\mathrm{R}=0.2553 \mathrm{C}_{(\mathrm{g} / \mathrm{ml})}+0.0533$} \\
\hline Determination coefficient $\left(\mathrm{r}^{2}\right)$ & $r^{2}=0.9994$ & \multicolumn{3}{|c|}{$r^{2}=0.9989$} \\
\hline Standard deviation of slope $\left(\mathrm{S}_{\mathrm{b}}\right)$ & $3.131 \times 10^{-3}$ & \multicolumn{3}{|c|}{$4.135 \times 10^{-3}$} \\
\hline Standard deviation of intercept $\left(\mathrm{S}_{\mathrm{a}}\right)$ & 0.121 & \multicolumn{3}{|c|}{0.161} \\
\hline Limit of detection (LOD) & 1.387 & \multicolumn{3}{|c|}{1.497} \\
\hline Limit of quantitation (LOQ) & 4.624 & \multicolumn{3}{|c|}{4.990} \\
\hline Confidence limit of the slope & $0.2506 \pm 0.0086$ & \multicolumn{3}{|c|}{$0.2553 \pm 0.0114$} \\
\hline Confidence limit of the intercept & $0.0773 \pm 0.3358$ & \multicolumn{3}{|c|}{$0.0533 \pm 0.4469$} \\
\hline Standard error of estimation & 0.131 & \multicolumn{3}{|c|}{0.173} \\
\hline \multicolumn{5}{|l|}{ Intra-day } \\
\hline $\begin{array}{c}\text { Mean of concentrations ( } \mathrm{g} / \mathrm{ml}) \mathrm{n}=3 \\
\text { S.D. } \\
\text { \% RSD }\end{array}$ & $\begin{array}{l}20.00 \\
60.02 \\
0.200 \\
0.070 \\
0.200 \\
0.069\end{array}$ & $\begin{array}{l}19.88 \\
0.400 \\
0.402\end{array}$ & $\begin{array}{l}39.94 \\
0.487 \\
0.488\end{array}$ & $\begin{array}{l}60.05 \\
0.230 \\
0.230\end{array}$ \\
\hline \multicolumn{5}{|l|}{ Inter-day } \\
\hline $\begin{array}{l}\text { Mean of concentrations ( } \mathrm{g} / \mathrm{ml}) \mathrm{n}=3 \\
\text { S.D. } \\
\text { \% RSD }\end{array}$ & $\begin{array}{l}20.08 \\
60.00 \\
0.200 \\
0.166 \\
0.199 \\
0.166\end{array}$ & $\begin{array}{l}19.84 \\
0.721 \\
0.726\end{array}$ & $\begin{array}{l}40.13 \\
0.300 \\
0.299\end{array}$ & $\begin{array}{l}59.58 \\
1.116 \\
1.124\end{array}$ \\
\hline \multicolumn{5}{|l|}{ Results } \\
\hline 1) Drug in bulk & $99.55 \pm 1.185$ & & $29 \pm 0.9$ & \\
\hline 2) Drug in dosage form & $97.68 \pm 0.793$ & & $94 \pm 0.7$ & \\
\hline 3) Drug added & $99.73 \pm 1.210$ & & $89 \pm 0.3$ & \\
\hline
\end{tabular}

Table 5: Tests of significance for the LC methods proposed for the determination of pipoxolan $\mathrm{HCl}$, drofenine $\mathrm{HCl}$ and propyphenazone in presence of their alkaline degradation products and isopropamide iodide - triflouperazine HCL binary mixture.

\begin{tabular}{|c|c|c|c|c|c|c|c|c|c|c|}
\hline & \multirow{2}{*}{\multicolumn{2}{|c|}{$\frac{\text { Method (I) }}{\text { Pipoxolan } \mathrm{HCl}}$}} & \multicolumn{4}{|c|}{ Method (II) } & \multicolumn{4}{|c|}{ Method (III) } \\
\hline \multirow{2}{*}{$\begin{array}{c}\text { Statistical } \\
\text { term }\end{array}$} & & & \multicolumn{2}{|c|}{ Drofenine $\mathrm{HCl}$} & \multicolumn{2}{|c|}{ Propyphenazone } & \multicolumn{2}{|c|}{ Isopropamide iodide } & \multicolumn{2}{|c|}{ Triflouperazine $\mathrm{HCl}$} \\
\hline & $\begin{array}{c}\text { Reference } \\
\text { method }^{\text {a }}\end{array}$ & $\begin{array}{c}\text { Proposed } \\
\text { method }\end{array}$ & $\begin{array}{l}\text { Reference } \\
\text { method }^{\mathrm{b}}\end{array}$ & $\begin{array}{l}\text { Proposed } \\
\text { method }\end{array}$ & $\begin{array}{l}\text { Reference } \\
\text { method }^{\mathrm{c}}\end{array}$ & $\begin{array}{c}\text { Proposed } \\
\text { method }\end{array}$ & $\begin{array}{c}\text { Reference } \\
\text { method }^{\mathrm{d}}\end{array}$ & $\begin{array}{c}\text { Proposed } \\
\text { method }\end{array}$ & $\begin{array}{c}\text { Reference } \\
\text { method }^{\text {e }}\end{array}$ & $\begin{array}{c}\text { Proposed } \\
\text { method }\end{array}$ \\
\hline Mean & 100.33 & 100.37 & 99.84 & 100.44 & 99.51 & 100.15 & 100.04 & 99.55 & 99.50 & 99.29 \\
\hline S.D. \pm & 0.587 & 1.101 & 0.584 & 0.905 & 0.795 & 0.798 & 0.788 & 1.185 & 0.584 & 0.902 \\
\hline S.E. \pm & 0.240 & 0.449 & 0.238 & 0.369 & 0.324 & 0.325 & 0.321 & 0.483 & 0.238 & 0.368 \\
\hline$\%$ RSD & 0.585 & 1.096 & 0.584 & 0.901 & 0.798 & 0.796 & 0.787 & 1.190 & 0.586 & 0.908 \\
\hline $\mathrm{n}$ & 6 & 6 & 6 & 6 & 6 & 6 & 6 & 6 & 6 & 6 \\
\hline $\mathrm{v}$ & 0.344 & 1.212 & 0.341 & 0.819 & 0.632 & 0.636 & 0.620 & 1.404 & 0.341 & 0.813 \\
\hline $\mathrm{t}(2.228)^{*}$ & \multicolumn{2}{|c|}{0.078} & \multicolumn{2}{|c|}{1.791} & \multicolumn{2}{|c|}{1.394} & \multicolumn{2}{|c|}{0.844} & \multicolumn{2}{|c|}{0.478} \\
\hline $\mathrm{F}(5.050)^{*}$ & \multicolumn{2}{|c|}{3.523} & \multicolumn{2}{|c|}{2.401} & \multicolumn{2}{|c|}{1.006} & \multicolumn{2}{|c|}{2.264} & \multicolumn{2}{|c|}{2.384} \\
\hline
\end{tabular}

*Figures in parentheses are the theoretical $\mathrm{t}$ and $\mathrm{F}$ values at $(\mathrm{p}=0.05)$.

${ }^{\text {a }}$ Spectrophotometric manufacturer's method(Amoun pharmaceutical Co. ${ }^{14}$.

${ }^{\mathrm{b}}$ Spectrophotometric manufacturer's method (Pharco Co. $)^{15}$.

${ }^{\mathrm{c}}$ Potentiometric method ${ }^{16} \quad{ }^{\mathrm{d}}$ Non-aquous titration method ${ }^{17} \quad{ }^{\mathrm{e}}$ Potentiometric method ${ }^{16}$. 


\section{Conclusion}

The proposed methods enables simple, accurate and reproducible quantitative RP-LC determinations of pipoxolan $\mathrm{HCl}$ in presence of its alkaline degradation products, a mixture of drofenine $\mathrm{HCl}$ and propyphenazone in presence of drofenine alkaline degradation product and isopropamide iodide and triflouperazine $\mathrm{HCl}$ binary mixture.

\section{REFERENCES}

1- S. C. Sweetman, "Martindale" The Complete Drug Reference, $36^{\text {th }}$ ed., London, 2009, pp. 119, 1727, 1736, 2368.

2- M. J. Sheu, P. Y. Chou, C. S. Huang, Y. C. Chien, I. C. Tasi, S. Y. Lin, H. Y. Tsai, H. C. Cheng and C. H. Wu, "Pipoxolan inhibits proliferation of HL-60 human leukaemia cancer cells by arresting the cell cycle at the G0/G1 phase", Clin. Exp. Pharmacol. Physiol., 37, 605 (2010).

3- F. C. Yuh, S. Y. Jia, W. H. Wen and Y. T. Huei, "Novel anti-leukemia activities of pipoxolan operate via the mitochondriarelated pathway in human leukemia U937 cells and attenuate U937 cell growth in an animal model", Molecular Medicine Reports., 3, 851 (2010). Through the internet site http//www.spandidospublications.com $/ \mathrm{mmr} / 3 / 5 / 851$.

4- E. Pawelczyk, R. Wachowiak and A. Reinholz, "Gas chromatography in drug analysis", Farm. Pol., 34, 99 (1978).

5- G. Ghilardelli, F. Rotilio, F. Zaccheo and M. Nannetti, "Determination of cycloadiphenine, diphenhydramine and ethyldiphenacetate by HPLC", Boll. Chim. Farm., 119, 483 (1980).

6- G. Facchini, F. Zaccheo and M. Nannetti, "Simultaneous determination of hydrochloride salts of adiphenine, diphenhydramine, ethyldiphenacetate, drofenine and promazine by ion-pair HPLC", ibid., 122, 405 (1983).

7- H. Yang and F. C. Thyrion, "Determination of six pharmaceuticals and their degradation products in RP-HPLC by using amine additives", J. Liq. Chromatogr. \& Rel. Technol., 21, 1347 (1998).
8- F. A. El-Yazbi, M. A. Korany, H. H. Abdine and M. A. Elsayed, "Derivative spectrophotometric determination of some tranquilizer-antidepressant mixtures", Spectrosc. Lett., 24, 437 (1991).

9- S. T. Hassib, B. A. Moussa, H. A. Hashim and A. A. El-Zaher, "Determination of certain antispasmodic drugs as single ingredient, mebeverine hydrochloride, and in two component mixtures, mebeverine hydrochloride-sulpiride and isopropamide iodide-trifluoperazine hydrochloride), ibid., 35, 43 (2002).

10- A. El-Gindy, B. El-Zeany, T. Awad and M. M. Shabana, "Spectrophotometric determination of triflouperazine $\mathrm{HCl}$ and isopropamide iodide in binary mixture using second derivative and second derivative of the ratio spectra methods", J. Pharm. Biom. Anal., 26, 203 (2001).

11- A. N. Abd-El-Hamid, "Simultaneous determination of phenylpropanolamine hydrochloride and isopropamide in capsule by HPLC using CROWNPAK column", Anal. Lett., 26, 1153 (1993).

12- K. C. Yiu, E. N. Ho and T. S. Wan, "Detection of quaternary ammonium drugs in equine urine by liquid chromatographymass spectrometry", Chromatographia., 59, 545 (2004).

13- S. M. Stanley and H. C. Foo, "Screening for basic drug in equine using directinjection differential-gradient LC-LC coupled to hybrid tandem MS/MS", J. Chromatogr. B: Anal. Tech. in the Biom. \& life Sci., 836, 1 (2006).

14- Manufacturer's method "Amoun Pharmaceutical Co.", personal communication.

15- Manufacturer's method (Pharco Co.), personal communication.

16- D. C. Beck, "The European Pharmacopoeia", The Council of Europe, Germany, 2008, pp. 3121, 2778.

17- "The United States Pharmacopoeia" (USP 32), National Formulary (NF 27), The United States Pharmacopeal Convention, 2009, p. 2702. 